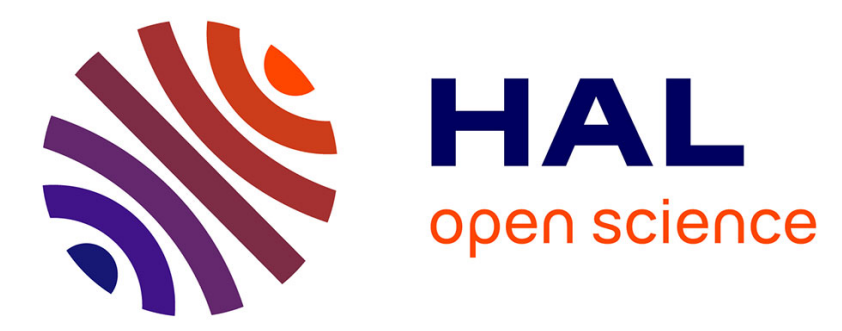

\title{
ERS scatterometer surface soil moisture analysis of two sites in the south and north of the Sahel region of West Africa
}

Mehrez Zribi, M. Pardé, Patricia de Rosnay, Frédéric Baup, N. Boulain, L. Descroix, T. Pellarin, Éric Mougin, C. Ottlé, B. Decharme

\section{To cite this version:}

Mehrez Zribi, M. Pardé, Patricia de Rosnay, Frédéric Baup, N. Boulain, et al.. ERS scatterometer surface soil moisture analysis of two sites in the south and north of the Sahel region of West Africa. Journal of Hydrology, 2009, 375 (1-2), pp.253-261. 10.1016/j.jhydrol.2008.11.046 . ird-00406277

\section{HAL Id: ird-00406277 https://hal.ird.fr/ird-00406277}

Submitted on 21 Jul 2009

HAL is a multi-disciplinary open access archive for the deposit and dissemination of scientific research documents, whether they are published or not. The documents may come from teaching and research institutions in France or abroad, or from public or private research centers.
L'archive ouverte pluridisciplinaire HAL, est destinée au dépôt et à la diffusion de documents scientifiques de niveau recherche, publiés ou non, émanant des établissements d'enseignement et de recherche français ou étrangers, des laboratoires publics ou privés. 


\title{
ERS scatterometer surface soil moisture analysis of two sites in the south and north of the Sahel region of West Africa
}

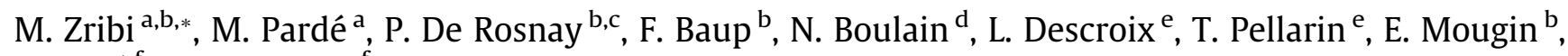 \\ C. Ottléf ${ }^{f}$ B. Decharme ${ }^{f}$ \\ ${ }^{a}$ CNRS/IPSL/CETP, 10-12 av. de l'Europe, 78140 Vélizy, France \\ ${ }^{\mathrm{b}}$ CESBIO, 18 Avenue, Edouard Belin, bpi 2801, 31401 Toulouse cedex 9, France \\ ${ }^{\mathrm{C}} \mathrm{ECMWF}$, Reading, RG2 9AX, United Kingdom \\ ${ }^{\mathrm{d}}$ HSM, BP_5045 Agropolis 34032 Montpellier, France \\ ${ }^{\mathrm{e}}$ LTHE, BP 53 Domaine Universitaire, 38041 Grenoble cedex 9, France \\ ${ }^{\mathrm{f}} \mathrm{CNRS/IPSL/Laboratoire} \mathrm{des} \mathrm{Sciences} \mathrm{du} \mathrm{Climat} \mathrm{et} \mathrm{de} \mathrm{l'Environnement,} \mathrm{Gif-sur-Yvette,} \mathrm{France}$
}

\section{A R T I C L E I N F O}

\section{Available online $\mathrm{xxxx}$}

\section{Keywords:}

Soil moisture

Time series analysis

Radar

ERS scatterometer

Western Africa

\begin{abstract}
S U M M A R Y
The analysis of feedback effects between continental surfaces and the atmosphere is a key element in the understanding of African monsoon dynamics. For this reason, the monitoring of surface parameters, in particular soil moisture, is essential. Satellite remote sensing appears to be the most suitable means of obtaining data relevant to such parameters. The present paper presents the results of statistical analysis of soil moisture products based on data recorded by the ERS scatterometer, over the period 1992-2006, from two sites in Niger and Mali in the Sahel climatic region. Soil moisture products were validated over these two sites using ground data measurements and ASAR/ENVISAT estimations. The soil moisture distribution during the monsoon period is described, and the temporal correlation between estimated soil moisture levels is computed. Finally, the dynamics of cells corresponding to precipitation events and high surface moisture values were evaluated in the studied regions, thereby revealing variations during the monsoon period as well as site specific trends.
\end{abstract}

(c) 2008 Elsevier B.V. All rights reserved.

\section{Introduction}

Surface soil moisture plays a crucial role in the continental water cycle, more specifically in the partitioning of precipitation between surface runoff and infiltration (Beven and Fisher, 1996), and in the partitioning of incoming radiation between latent and sensible heat fluxes. As a consequence, soil moisture influences the flux of atmospheric water vapour and precipitation.

In the case of African Monsoons, the feedback effect arising from the influence of continental surfaces on monsoon dynamics is often assumed to have played an important role in the drought of the 70s and 80s. The theories of Charney (1975) or Eltahir and Gong (1996) address this question on the regional scale, whereas other studies (e.g. Taylor and Lebel, 1998) raise the hypothesis of continental surface feedback at convective scales. In a study made by (Koster et al., 2004), the significant role of soil moisture on precipitation patterns in different regions of the globe, particularly West Africa, is illustrated. In these different studies, the importance of taking both atmospheric dynamics and continental water

\footnotetext{
* Corresponding author. Address: CNRS/IPSL/CETP, 10/12, Avenue de l'Europe, 78140 Velizy, France. Tel.: +33 1392549 34; fax: +33 139254922.

E-mail address: zribi@cetp.ipsl.fr (M. Zribi).
}

dynamics into consideration (interactions between horizontal water transfer, soil water storage, and vegetation dynamics) is shown. Whereas the regular measurement of soil surface characteristics (moisture and vegetation) in these regions poses a substantial challenge, considerable efforts have been made, over the past 3 decades, to develop remote sensing techniques for the characterisation of the spatial and temporal variability of soil moisture over large regions (Ulaby et al., 1986). In al., 1986). "In particular, active and passive microwave techniques as well as interpretation tools have been developed (Jackson et al., 1996).

In (Zribi et al., 2008), the authors propose a new methodology for surface soil moisture estimations over West Africa, based on the reduction of ERS scatterometer data recorded with a grid resolution equal to $0.25^{\circ} \times 0.25^{\circ}$.

In the present study, our objective has been to analyse these surface moisture products, for two geographically different sites in the Sahel, with particular emphasis being placed on the African monsoon season. Our study is based on 11 years of data, collected between (1992-2000) and (2004-2006).

The present paper is organised as follows: "Data and studied sites" presents the surface soil moisture product and provides a brief description of the land-cover and bioclimatic features of the sites studied in Niger and Mali. "Validation over the two studied 
sites during the AMMA experimental campaigns (2005-2006)" discusses the validation of ERS data for the two sites. "Statistical analysis of ERS soil moisture products" describes the differing statistical behaviour of surface soil moisture products. Finally, we present our conclusions in "Conclusion".

\section{Data and studied sites}

In the context of the African Monsoon Multidisciplinary Analysis (AMMA), the two super-site, proposed in our paper, were selected in the Sahel region. Two networks of soil moisture measurements were specifically designed, coherently at the two sites, for remote sensing applications and retrieval method validation. For passive microwaves, the sites are selected for validation of the future sensor SMOS (Soil moisture and Ocean Salinity, Kerr et al., 2001which is an L band radiometer, dedicated for soil moisture and ocean salinity estimations. They were also used for AMSRE radiometer products validation (Pellarin et al., 2008, Gruhier et al., 2008). For active remote sensing, different approaches have been developed, particularly with ASAR/ENVISAT high resolution data $(12.5 \times 12.5 \mathrm{~m})$ for soil moisture mapping (Zribi et al., 2006; Baup et al., 2007a,b). ESA launched ENVISAT with the ASAR radar in March 2002. It offers particularly a large improvement in the repetitiveness of measurements (less than 5 days comparing to 35 days for ERS/SAR). It functions with different configurations (multi-incidence angles, multi-polarisations and multi-resolutions) with a wave length equal to $5.6 \mathrm{~cm}$ (C-band).

\section{Niger site}

The studied region is located in the South West of Niger, East of the Niger River (Fig. 1) and covers an area of four square degrees $\left(13-15^{\circ} \mathrm{N}, 3-5^{\circ} \mathrm{E}\right)$. Part of this area was defined in 1992 for the purposes of the international Hapex-Sahel survey (Goutorbe et al., 1997). The Sahelian climate in this region is semi-arid, with an average annual rainfall ranging between 300 and $750 \mathrm{~mm}$ per year, characterised by a rainy season lasting from June to September (corresponding to the Monsoon period).

The landscape is mainly flat, and is dominated by dissected plateaux with slopes of less than $6 \%$. The plateaux have lateritic soils and are covered with tiger bush. They are bordered largely by terrain with strong transitional features and steep inclines, which can reach a slope of $35 \%$. The vegetation in the valleys is dominated by cultivated (mainly millet) and fallow fields. As noted by (Zine et al., 2005), the millet fields are situated in sparsely covered valley floors with less than 1 plant per $\mathrm{m}^{2}$. The 'bare soil' and 'sparse vegetation' classes represent approximately 53\% of the surface area of the studied region. Fig. 2a illustrates the dynamics of the vegetation for four different years. In this illustration, we used the Normalized Difference Vegetation Index (NDVI) produced by the NOAA Advanced Very High Resolution Radiometer (NOAA-AVHRR). This index, given by the ratio of the difference between the visible and near-infrared channels to the sum of these two channels, is linked to green vegetation photosynthetic activity. Data corresponding to recordings made at one month intervals, with a spatial resolution of $0.25^{\circ} \times 0.25^{\circ}$, was downloaded from the website http://cybele.bu.edu and averaged in the studied site. The vegetation is observed to have a maximum growth rate towards the end of August or the beginning of September, and overall growth is found to vary from one year to another, according to fluctuations in annual precipitation.

\section{Description of soil moisture measurements}

Three Water content reflectometers (Campbell Scientific, 2002) were installed for continuous estimation of soil moisture at various depths between $0.05 \mathrm{~m}$ and $1.7 \mathrm{~m}$ : they were located in three small areas in the Kori Diantandou basin: Wankama $\left(13.65^{\circ} \mathrm{N}, 2.65^{\circ} \mathrm{W}\right)$, Tondi Kiboro $\left(13.55^{\circ} \mathrm{N}, 2.7^{\circ} \mathrm{W}\right)$ and Banizoumbou $\left(13.53^{\circ} \mathrm{N}\right.$, $2.66^{\circ} \mathrm{W}$ ). These instruments use time domain reflectometry (TDR) to estimate the apparent permittivity of soil, which in turn can be related to the soil water content. They have been continuously measuring soil moisture, at 30-min time intervals, since June 2006. Fig. 3a illustrates the measured soil moisture dynamics at the Tondi Kiboro site. The periods of increasing soil moisture correspond to precipitation events.

\section{Gourma mesoscale site}

The Gourma region (Fig. 1) is located entirely within the Sahel bioclimatic zone $\left(15-17^{\circ} \mathrm{N}, 0-2^{\circ} \mathrm{W}\right)$. This is a mainly pastoral region, with boundaries defined by the annual average rainfall isohyets of 500 and $150 \mathrm{~mm}$. The rain distribution is strictly monomodal, with rainfall lasting between June and September, and a maximum occurring in August. The rainy season is then followed by a long dry season, characterized by the absence of green vegetation apart from some scattered trees and shrubs. Rangeland vegetation is composed of a herbaceous layer and a sparse woody plant population. Herb growth is strongly influenced by the pattern and magnitude of rainfall events, and by the soil moisture regime which ensues, coupled with the local run-off characteristics which are influenced by topography and soil texture. Annual herbs germi-

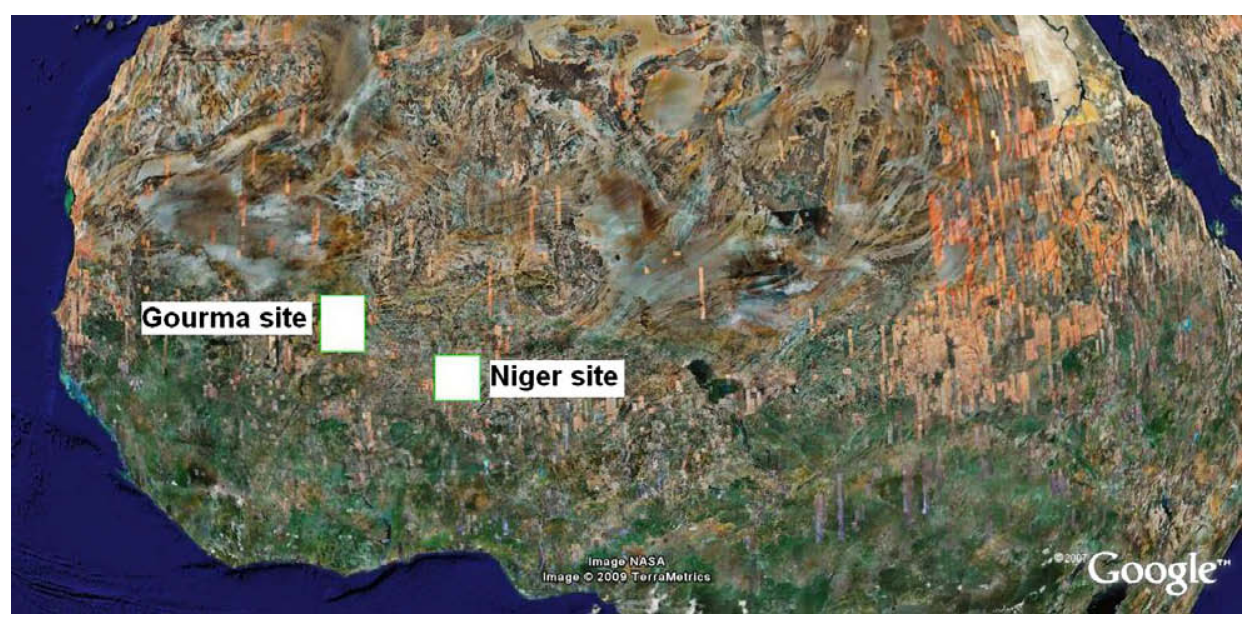

Fig. 1. Illustration of Western Africa showing the location of the two studied sites (white windows). 

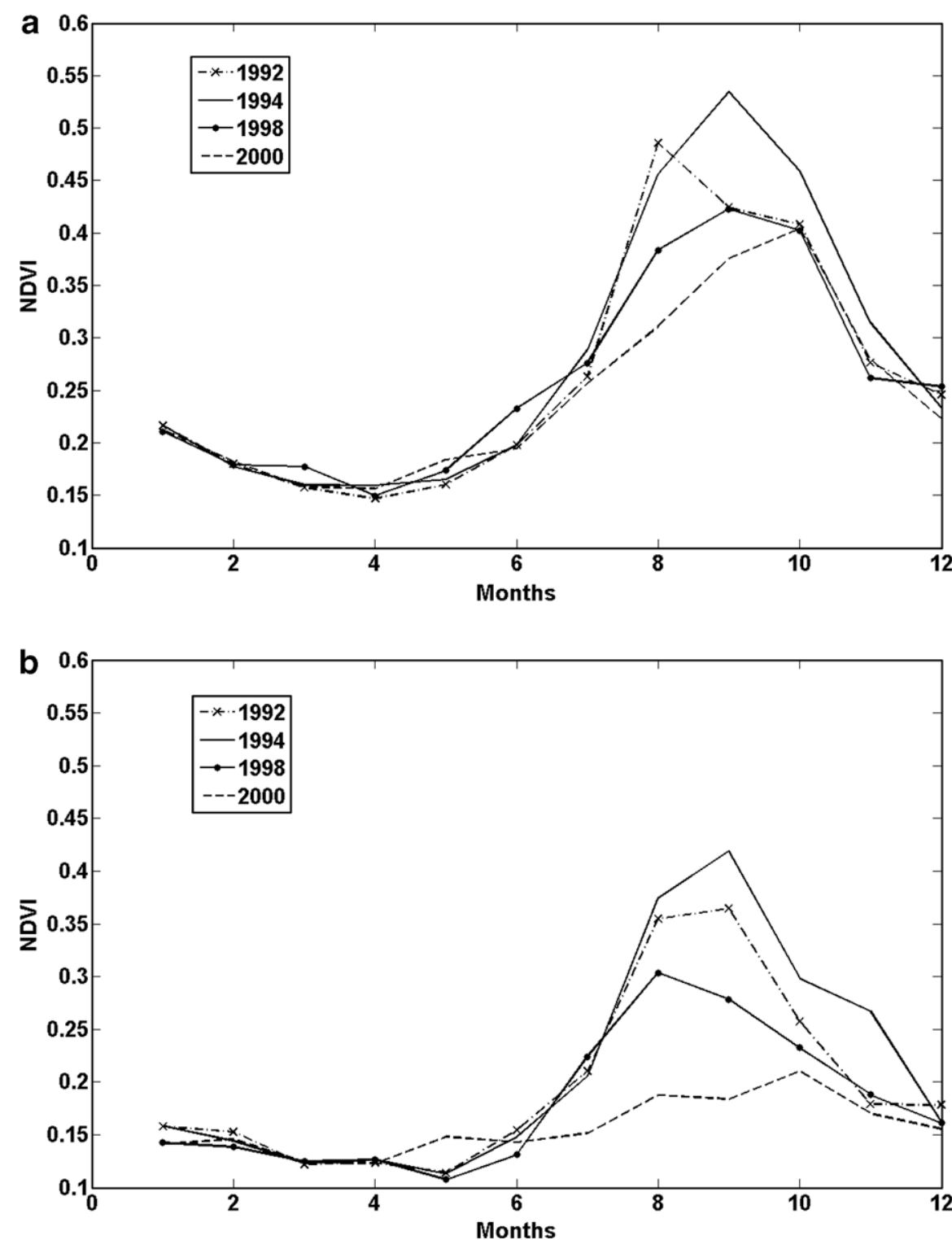

Fig. 2. Illustration of vegetation dynamics for different years: (a) Niger $\left(13^{\circ}-15^{\circ} \mathrm{N}, 3^{\circ}-5^{\circ} \mathrm{E}\right)$ and (b) Mali $\left(15^{\circ}-17^{\circ} \mathrm{N}, 0^{\circ}-2^{\circ} \mathrm{W}\right)$.

nate after the first rains in June or July and unless the plants wilt before reaching maturity, owing to a lack of rainfall, senescence coincides closely with the end of the rainy season. Fig. 2b illustrates, for the Mali site, the NDVI dynamics during four different years. The growth peak in this site corresponds approximately to the end of September.

\section{Description of soil moisture measurements}

As the soil moisture measurements were specifically designed for remote sensing applications and retrieval method validation (Baup et al., 2007a,b; Gruhier et al., 2008), nine local soil moisture stations were installed (the locations of these stations are listed in De Rosnay et al. (2009)). Water content reflectometers are generally used (Campbell Scientific, 2002). They provide soil measurements with a very fine vertical resolution, and include recordings taken at a depth of $5 \mathrm{~cm}$. These local stations have been continuously measuring soil moisture and temperature profiles, at 15min time intervals, since July 2004. Gravimetric measurements are carried out in order to calibrate the soil moisture sensors at the local scale. The surface soil moisture (SSM) is expressed in $\mathrm{m}^{3} / \mathrm{m}^{3}$ (volumetric soil water content). An example is given in
Fig. 3b, which illustrates the dynamics of measured soil moisture at the local station no. 17, in 2006.

\section{ERS scatterometer moisture products}

The ERS wind scatterometer was initially designed to measure wind speed and direction at the sea's surface. However, a large number of scientific studies have been developed over the last decade, making use of this active sensor for continental surface applications (Frison and Mougin, 1996; Wagner et al., 1999; Wagner and Scipal, 2000; Zribi et al., 2003). The instrument consists of three radar antennae which are pointed $45^{\circ}$ forwards, $45^{\circ}$ sideways, and $45^{\circ}$ backwards with respect to the satellite's nadir. The incidence angle $\theta$ varies over the instrument's swath, between $18^{\circ}$ and $47^{\circ}$ for the mid-beam antenna, and between $25^{\circ}$ and $59^{\circ}$ for the fore- and aft-beam antennae (Frison and Mougin, 1996). Once the data has been reduced, each observed cell is thus associated with measurements derived from three different angles of incidence. The sensor operates at $5.3 \mathrm{GHz}$ and $\mathrm{VV}$ polarisation, like the ERS/SAR instrument. Its spatial resolution is approximately $50 \mathrm{~km}$, and the repeat cycle is every $3-4$ days. The data is pro- 

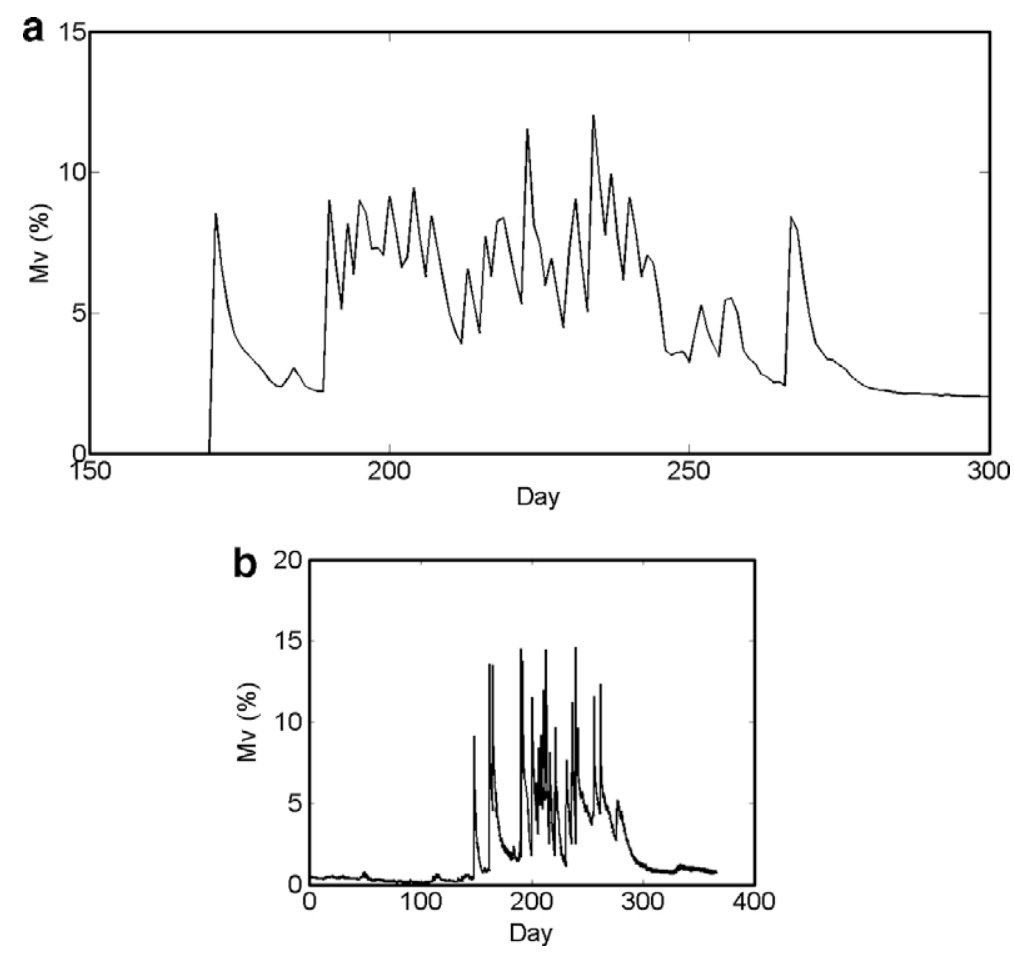

Fig. 3. Illustration of temporal soil moisture dynamics: (a) Niger site and (b) Mali site.

cessed using a grid, and our studied region (West Africa) was divided into elementary $0.25^{\circ}$ square cells.

The authors have developed a methodology which enables surface soil moisture to be estimated from ERS radar wind scatterometer data, with a resolution equal to $25 \mathrm{~km}$ (Zribi et al., 2008). The raw data is processed in three stages

(1) Normalisation of the data to a single incidence angle $\left(40^{\circ}\right)$.

(2) Elimination of surface roughness effects using an estimation of the dry soil signal corresponding to the same roughness and vegetation as the acquired radar signal.

(3) Reduction of the influence of vegetation on the radar signal's sensitivity to soil moisture, using the NDVI index derived from AVHRR measurements.

The proposed methodology, limited to regions with NDVI lower than 0.5 , has been validated using different approaches, and a high level of consistency is found between measured soil moisture variations and rainfall events (Zribi et al., 2008). Secondly, comparisons between ground data measurements acquired in 1992 during the HAPEX campaigns and the soil moisture values derived using our methodology are characterised by an rms relative difference of only $2.4 \%$. A good degree of coherence was found between the soil moisture output given by GSWP2 multi-model analyses, and our reduction of ERS satellite data. Soil moisture maps are proposed for the studied period from 1992 to 2006, with the exception of the years 2001-2003.

\section{Validation over the two studied sites during the AMMA experimental campaigns (2005-2006)}

Comparison with ground data measurements from Niger made in 2006

Fig. 4 provides a comparison between ERS soil moisture estimations, ASAR estimations at the same scale $(25 \times 25 \mathrm{~km})$, and ground measurements recorded using three TDR at three test sites:

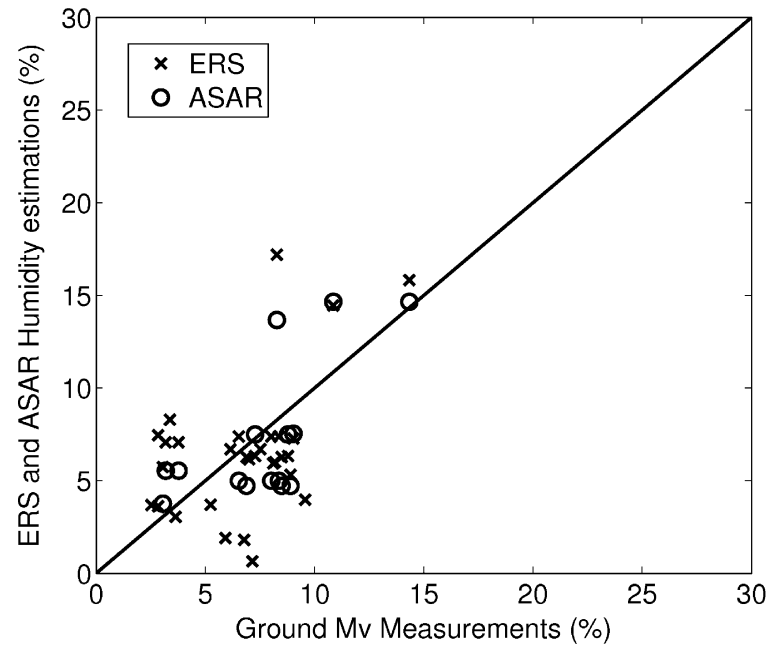

Fig. 4. Inter-comparison between ground data and ERS $(\times)$ and ASAR $(O)$ surface soil moisture products for the Niger.

Table 1

Statistical parameters for inter-comparison between locally measured and ERS-ASAR estimations of soil moisture.

\begin{tabular}{lll}
\hline & RMSE (\%) & $R^{2}$ \\
\hline ERS - Ground & 3.3 & 0.46 \\
ASAR - Ground & 2.8 & 0.62 \\
\hline
\end{tabular}

Wankama, Banizoumbou and Tondi Kiboro. In Table 1, we present computed rms errors and $R^{2}$ values, resulting from comparisons between ground moisture measurements and both ERS and ASAR data. Some of the differences between measured and remotely sensed soil moisture values could be explained by the fact that ground measurements correspond to a mean soil moisture level, since only two local measurements are used for each site. Differ- 


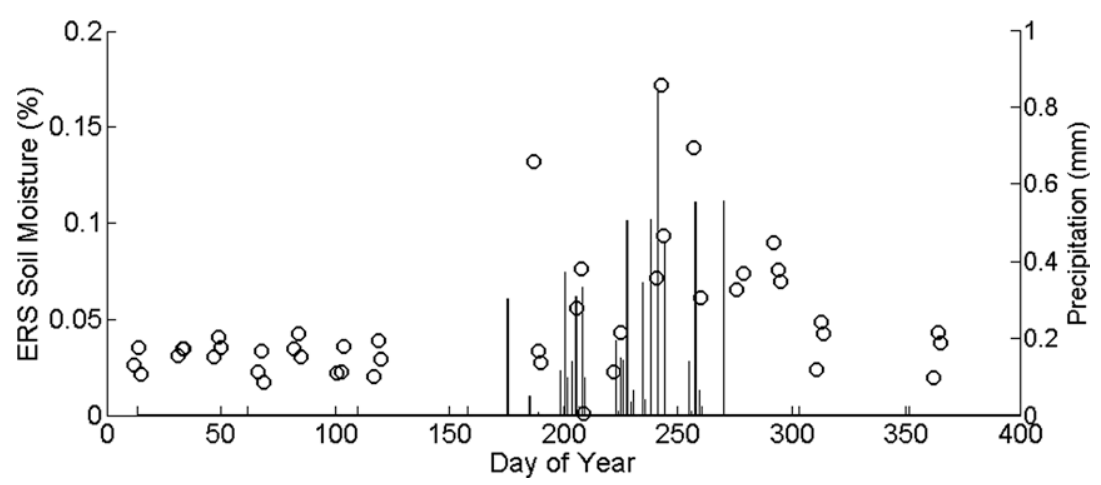

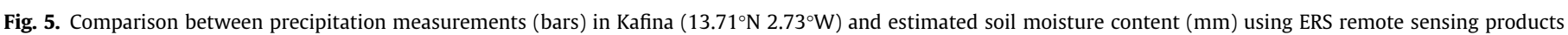
(circles).

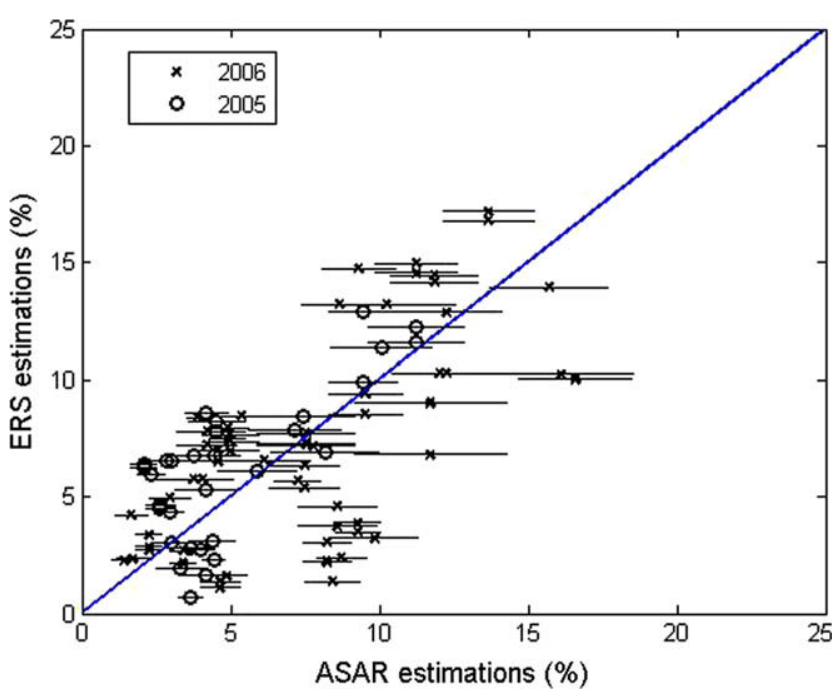

Fig. 6. Inter-comparison between ERS and mean values of ASAR/ENVISAT products over different grids in Niger site.

ences in scale estimation can also lead to errors. Fig. 5 illustrates the dynamic of soil moisture ERS estimations and precipitation over one grid in 2006. It shows the high consistency of moisture variation with precipitation events.
Validation with ASAR/ENVISAT moisture products for the Niger site

The second type of validation of ERS products, established for the Niger site, is based on comparisons with low-incidence, high resolution ASAR/ENVISAT radar mapping data recorded during the 2005 and 2006 seasons (Zribi et al., 2006). The methodology proposed for ASAR/ENVISAT inversion was broken down into several successive steps:

(1) IS1 and IS2 radar data are normalised to one incidence angle equal to $20^{\circ}$,

(2) For each cell, areas corresponding to pools, high slopes (greater than 3\%) and high density vegetation (NDVI higher than 0.25 ) are masked,

(3) Roughness effects are eliminated by subtracting radar data recorded during the dry season from that used for soil moisture determination,

(4) Soil moisture is retrieved, by inverting a linear relationship between the processed signals and soil moisture.

This mapping approach has been validated at different test sites in Niger (Zribi et al., 2006). More than 15 mapping dates are proposed during the 2005 and 2006 monsoon periods, for the Kori Dantiandou basin. As shown in Fig. 6, despite the low number of dates for which both types of satellite measurement were recorded, we observe a strong degree of coherence between the two types of estimation, based respectively on ASAR and ERS scatt-

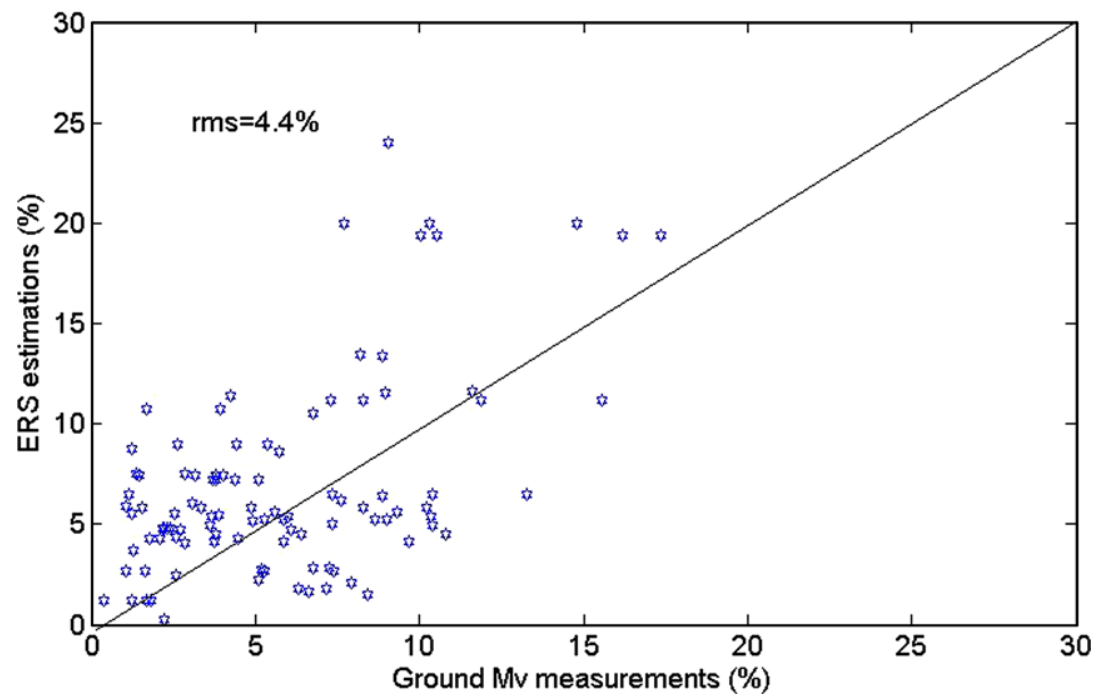

Fig. 7. Inter-comparison between ground data and ERS surface soil moisture products over the Mali site. 
erometer data, with a small discrepancy corresponding to an rms error equal to $3.1 \%$. These comparisons are made over the ERS product grids. For each grid, a mean value of ASAR/ENVISAT derived soil moisture is used, with a mapping resolution of $1 \mathrm{~km}$. Although comparisons between the two products are made on the same dates, large differences in estimated moisture were found, because of time differences between the instants of ASAR and ERS data acquisition. The spatial variance of the ASAR estimations, based on the scale of the ERS grid, is also illustrated. Spatial variations in soil moisture are related mainly to variations in rainfall and vegetation cover over the ERS grid.

\section{Comparison with ground data measurements in Mali in 2005-2006}

Fig. 7 provides a comparison between ERS estimations and ground data measurements recorded at different test sites. It shows a good degree of agreement, with an rms error of $4.4 \%$.
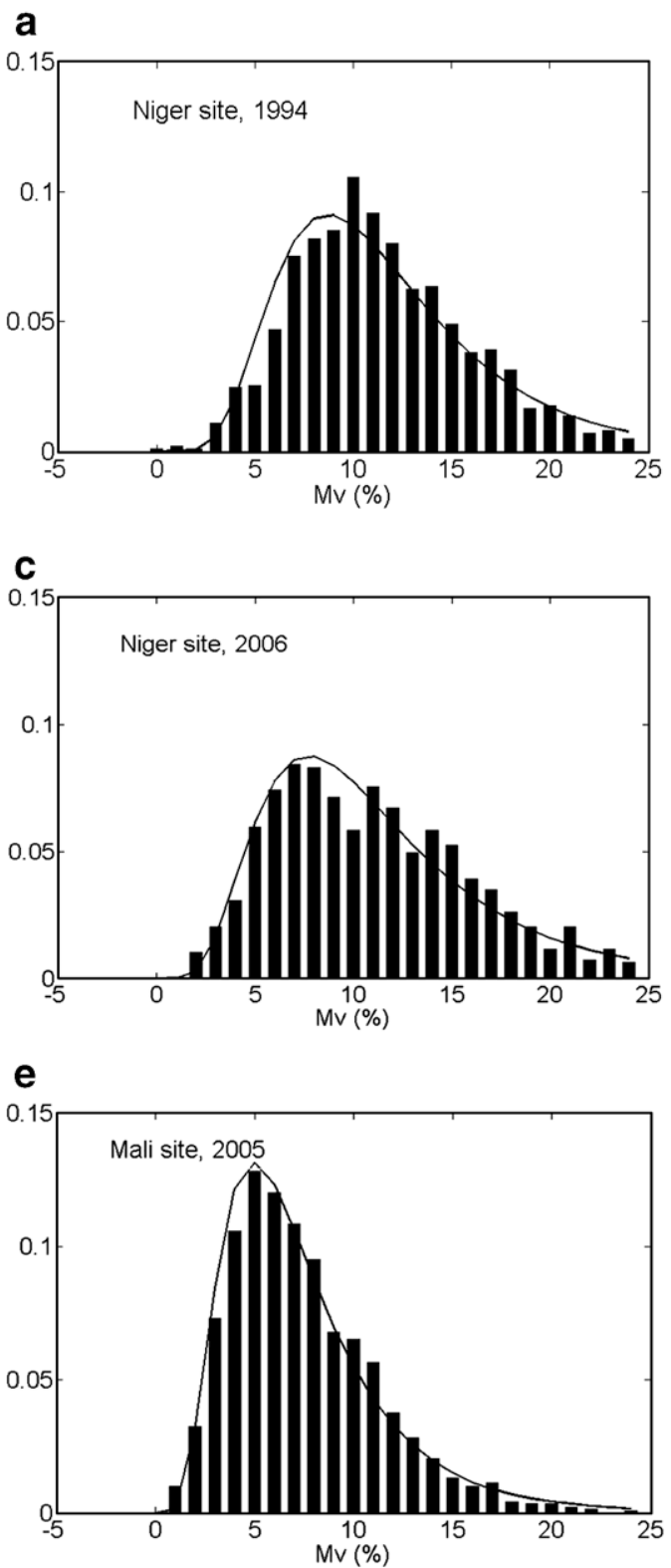

The main source of discrepancy between the two sets of measured data is the large difference between the spatial scales used for each type of estimation.

In conclusion, despite some limitations of the validation approach based on the use of ground scale measurements, we have been able to demonstrate the robustness of the ERS soil surface moisture product for the two studied sites. In the next section, we analyse the statistical behaviour of all ERS products for the periods 1992-2000 and 2004-2006. No data was available for the period 2001-2003.

\section{Statistical analysis of ERS soil moisture products}

The objective of this section is to analyse the behaviour of soil moisture over two studied sites, situated in two different climatic regions, in the South and North of the Sahel.
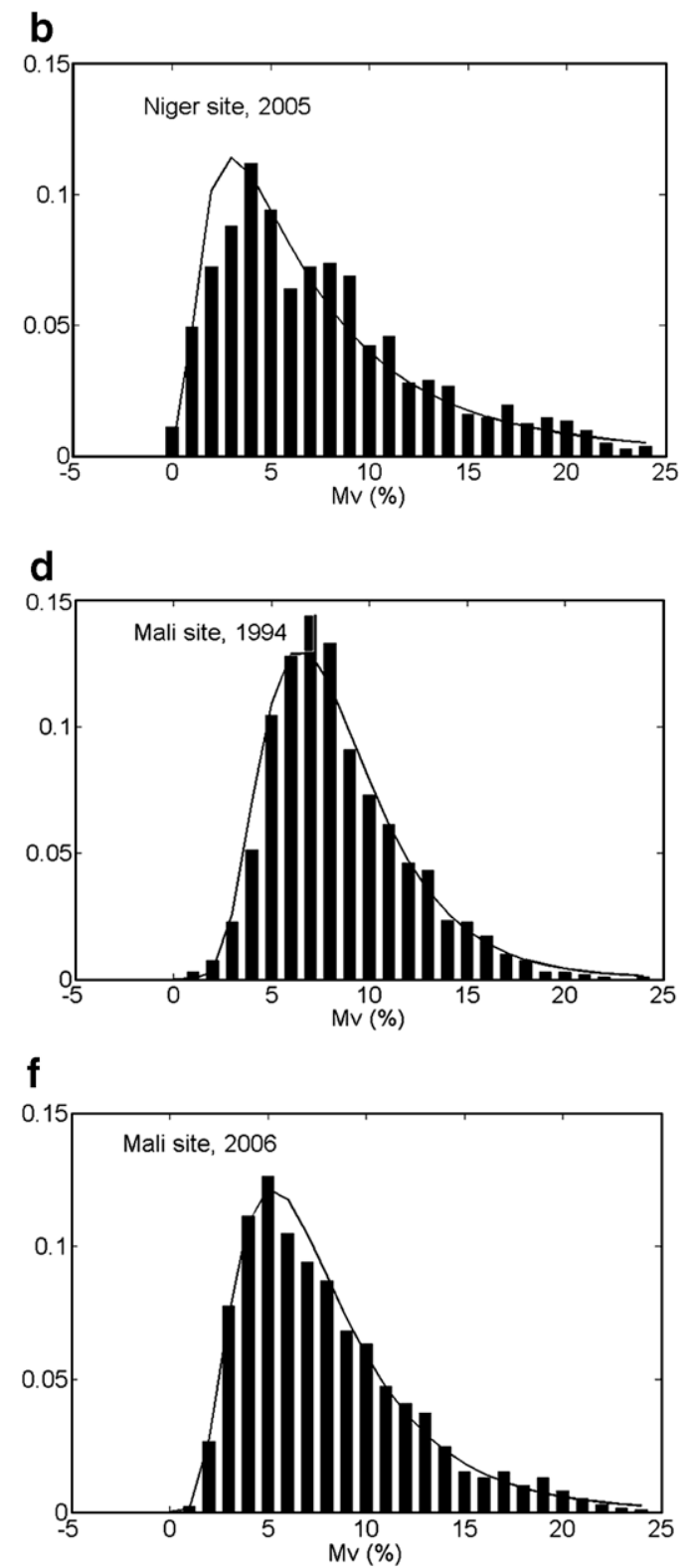

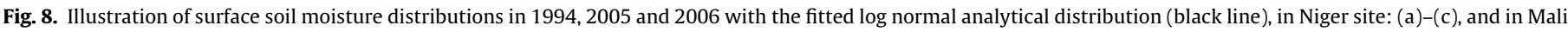
site: (d)-(f) 


\section{Surface soil moisture distribution}

In order to study the behaviour of surface soil moisture during the monsoon period, we propose to analyse its temporal variations. The aim of the work described in this section is to evaluate the ability of ERS products to reproduce the statistical behaviour of surface soil moisture. Fig. 8 illustrates the distribution of soil moisture during the monsoon period (July-October) at the two studied sites, for three one-year periods: 1994, 2005 and 2006. 1994 was an exceptionally wet year, and 2005-2006 coincides with the period during which the AMMA experimental campaigns were made. We fitted the experimental distributions with a log-normal analytic function:

$F(x)=\frac{1}{\sigma \sqrt{2 \pi x}} \exp \left(\frac{-1}{2}\left(\frac{\ln x-\mu}{\sigma}\right)^{2}\right)$

where $\sigma$ and $\mu$ are two adjusted parameters, and $x$ is the variable corresponding to the soil moisture dependence.

Table 2 shows the values of the two parameters, $\mu$ and $\sigma$, for the different years studied in our paper, with the corresponding mean value of precipitation over West Africa. This result illustrates the strong consistency between surface moisture distribution and annual precipitation. We observe a large difference between the computed soil moisture for 1994 (a wet year) and 1992 (a dry year), characterised by a large difference in the parameter $\mu$ (equal to 1.63 for 1992 and 2.37 for 1994). Between the Niger and Mali sites, the difference in distributions is also evident, with the mean value of $\mu$ being generally lower for the Mali region (north Sahel) than for the area studied in Niger.

\section{Temporal correlation between soil moistures}

In order to analyse the temporal behaviour of soil moisture over a given site, we chose to analyse the temporal correlation between measurements. By assuming variations in soil moisture to be a stationary function, we use the following expression to estimate the correlation function value in the two studied regions:

$\rho(t)=\left\langle m v\left(d_{i}\right) \cdot m v\left(d_{i}+\tau\right)\right\rangle$

where $\tau$ is the number of days between two measurements.

As the ERS products are available only 4 to 7 times per month (due to the coverage patterns resulting from the satellite's orbit), for some values of $\tau$ there is no correlation with remotely sensed data. In order to achieve a good statistical representation for the correlation function, this is determined using values of $\tau$ for which the calculations involve more than 20 events with moisture estimated at $d_{i}$ and $d_{i}+\tau$. Fig. 9 shows the resulting correlations, in the Niger region, for different years. A strong decrease in correlation between two events can be observed, after a period of one day. This is due to two factors: first, the high rate of evaporation in the two studied sites leads to high temporal variations in soil moisture, particularly after a precipitation event. Second, the pre-

Table 2

Estimation of log-normal distribution parameters, with annual precipitations, during the studied period (1992-2006), for Niger and Mali sites.

\begin{tabular}{|c|c|c|c|c|c|c|}
\hline \multirow[t]{2}{*}{ Year } & \multicolumn{3}{|c|}{ Niger } & \multicolumn{2}{|l|}{ Mali } & \multirow[b]{2}{*}{ Annual precipitations (mm) } \\
\hline & $\mu$ & $\sigma$ & Annual precipitations (mm) & $\mu$ & $\sigma$ & \\
\hline 1992 & 1.63 & 0.95 & 538 & 0.94 & 0.86 & 280 \\
\hline 1993 & 1.3 & 0.96 & 454 & 1.08 & 0.9 & 303 \\
\hline 1994 & 2.37 & 0.45 & 666 & 2.05 & 0.42 & 585 \\
\hline 1995 & 1.81 & 0.97 & 497 & 1.41 & 0.66 & 373 \\
\hline 1997 & 1.35 & 0.97 & 408 & 1.26 & 0.89 & 225 \\
\hline 1998 & 1.88 & 0.79 & 655 & 1.94 & 0.72 & 409 \\
\hline 1999 & 2.2 & 0.57 & 554 & 2.16 & 0.59 & 556 \\
\hline 2000 & 1.77 & 0.83 & 430 & 1.78 & 0.64 & 291 \\
\hline 2004 & 1.66 & 0.91 & 531 & 1.53 & 0.56 & 185 \\
\hline 2005 & 1.78 & 0.83 & 571 & 1.87 & 0.54 & 334 \\
\hline 2006 & 2.31 & 0.52 & 542 & 1.94 & 0.54 & 369 \\
\hline
\end{tabular}

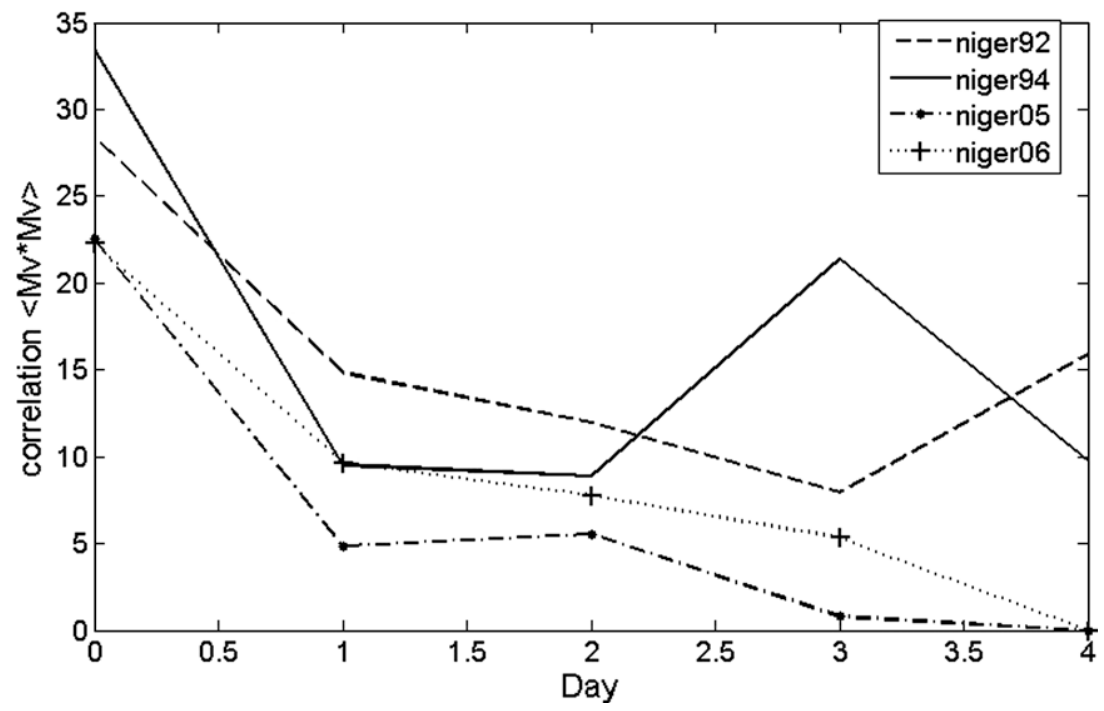

Fig. 9. Temporal correlation of surface soil moistures during the monsoon period in the Niger site 


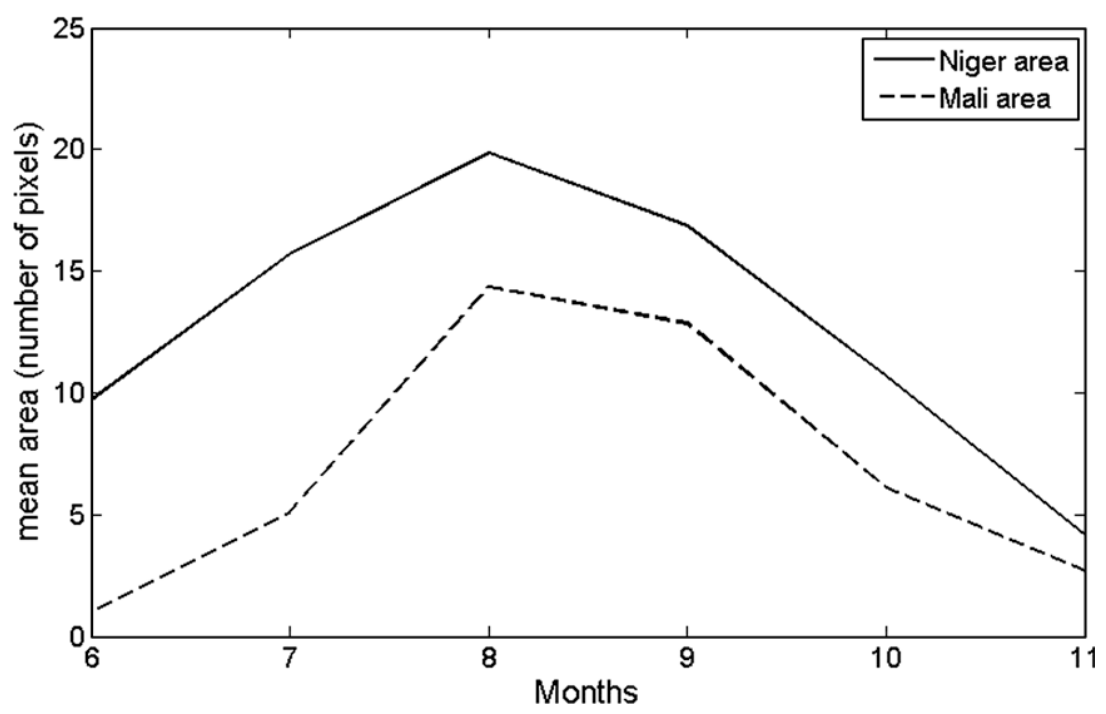

Fig. 10. Evolution of the extent of high moisture areas during the monsoon period, for the two studied sites.

cipitation is highly variable in these regions, with large precipitation cells occurring at low frequencies during the monsoon season. For these reasons, the variations in shape of the correlation function, from one year to the next, are not necessarily due to variations in rainfall. This result illustrates the high temporal variability of surface soil moisture, shown by (Baup et al., 2007a,b), with a very high decrease of moisture after rain events.

\section{Spatial behaviour of soil moisture}

The aim of this section is to analyse the temporal dynamics of precipitation cell areas, for two studied sites situated in two different climatic regions. From experimental ground measurements, we observe an increase of volumetric moisture to an approximate minimum of $8-10 \%$ for precipitation events. With the objective of discussing precipitation cell areas dynamics in mind, we consider only rainfall events occurred at dates for which the surface soil moisture was higher than $10 \%$. For a given day $d$, a cell is defined by the amalgamation of grid pixels in which the soil moisture is higher than $10 \%$, over the studied site.

Using these assumptions, Fig. 10 illustrates the variation in mean cell area (number of grid pixels) characterised by higher soil moisture content, for the period between June and November. This computation is based on statistics taken over a period of 11 years. It can be observed that for both sites, the maximum cell area occurs during the month of August. This result is in coherence with vegetation growth dynamic, illustrated in Fig. 2. In fact, we observe clearly a gap of vegetation maximum growth which is generally observed in September. In addition, it can be seen that smaller mean cell sizes occur for the Mali site. This effect is not necessarily due to a smaller size of precipitation cells, since it can also be accounted for by very high evaporation rates in the northern regions, which lead to a rapid decrease in soil moisture following a precipitation event (De Rosnay et al., 2009).

\section{Conclusion}

Surface soil moisture products, estimated from ERS scatterometer data, have been analysed for two sites in the south and north of the Sahel region of West Africa. We provide validation of the ERS products, based on ground data measurements and ASAR/ENVISAR radar products with a higher resolution. Surface soil moisture analysis has shown the potential of this parameter for the characterisa- tion of these two different sites. Firstly, a strong correlation is observed between soil moisture distributions and the wetness of each year. Secondly, differences are observed between the distributions corresponding to the Sahel and the northern desert regions. Temporal surface moisture correlations observed in one of the studied sites demonstrate the very high temporal variation of soil moisture in West Africa. This is due, in particular, to high rates of evaporation and the low frequency of precipitation events. Finally, the extent of high moisture areas related to precipitation events shows a cyclic behaviour from June to November, with a maximum occurring in August, in coherence with vegetation growth pick observed in September. These areas are smaller in the north, mainly because of very high rates of evaporation.

Apart from the use of the described soil moisture products as inputs for flux modelling, the statistical analysis described here demonstrates their potential role in improving our understanding of monsoon dynamics in this region.

\section{Acknowledgements}

Based on a French initiative, AMMA was formed by an international scientific group, and is currently funded by a large number of agencies, in particular from France, the UK, the USA and Africa. It also benefits from a major financial contribution provided by the European Community's Sixth Framework Research Programme. Detailed information on the scientific coordination and funding of AMMA is available at its international web site: http://www.amma-international.org/.

The authors would like to thank the European Space Agency (ESA) for providing them with ERS data and ASAR images free of charge, in the framework of projects n 1522 and 4472. The authors would also like to thank the Niamey-IRD and CESBIO teams for their logistic support during terrain and rainfall measurement surveys carried out in Niger and Mali.

\section{References}

Baup, F., Mougin, E., Hiernaux, P., Lopes, A., deRosnay, P., Chênerie, I., 2007a. Signatures of Sahelian surfaces in Mali using ENVISAT-ASAR data. IEEE Transaction on Geoscience and Remote Sensing 45 (7), 2354-2363.

Baup, F., Mougin, E., de Rosnay, P., Timouk, F., Chênerie, I., 2007b. Surface soil moisture estimation over the AMMA Sahelian site in Mali using ENVISAT/ASAR data. Remote Sensing of Environment 109 (4), 473-481.

Beven, K.J., Fisher, J., 1996. Remote sensing and scaling in hydrology, scaling in hydrology using remote sensing. In: Stewart, J.B. et al. (Eds.), Scaling Issues in Hydrology, Wiley, Chichester. 
Campbell Scientific, 2002. CS616 Water Content Reflectometer, User Guide, Issued 6.3.02.

Charney, J.G., 1975. Dynamics of deserts and droughts in the Sahel. Quarterly Journal of the Royal Meteorological Society 101, 193-202.

De Rosnay, P., Gruhier, C., Timouk, F., Mougin, E., Hiernaux, P., Kergoat, L., LeDantec V., 2009. Multi-scale soil moisture measurements over the Gourma meso-scale site in Mali. Journal of Hydrology, accepted for publication.

Eltahir, E.A.B., Gong, C., 1996. Dynamics of wet and dry years in West Africa. Journal of Climate 9, 1030-1042.

Frison, P.L., Mougin, E., 1996. Use of ERS-1 wind scatterometer data over land surfaces. IEEE Transactions on Geoscience and Remote Sensing 34, 1-11.

Goutorbe, J.P., Lebel, T., Dolman, A.J., Gash, J.H.C., Kabat, P., Kerr, Y.H., Monteny, B. Prince, S.D., Stricker, J.N.M., Tinga, A., Wallace, J.S., 1997. An overview of HAPEXSahel: a study in climate and desertification. Journal of Hydrology 188-189, 417.

Gruhier, C., de Rosnay, P., Kerr, Y., Mougin, E., Ceschia, E., Calvet, J.-C., 2008. Evaluation of AMSR-E soil moisture products based on ground soil moisture measurements over temperate and semi-arid regions. Geophysical Research Letter 35. doi:10.1029/2008GL03330.

Jackson, T.-J., Schmugge, J., Engman, E.-T., 1996. Remote sensing applications to hydrology: soil moisture. Hydrological Sciences 41 (4), 517-530.

Kerr, Y.H., Waldteufel, P., Wigneron, J.-P., Martinuzzi, J.-M., Font, J., Berger, M., 2001. Soil moisture retrieval from space. The Soil Moisture and Ocean Salinity (SMOS) mission. IEEE Transactions on Geoscience and Remote Sensing 39 (8), 17291735.

Koster, R.D., Dirmeyer, P.A., Guo, Zhichang, Bonan, Gordon, Chan, Edmond, Cox Peter, Gordon, C.T., Kanae, Shinjiro, Kowalczyk, Eva, Lawrence, David, Liu, Ping, Lu, Cheng-Hsuan, Malyshev, Sergey, McAvaney, Bryant, Mitchell, Ken, Mocko David, Oki, Taikan, Oleson, Keith, Pitman, Andrew, Sud, Y.C., Taylor, Christopher
M., Verseghy, Diana, Vasic, Ratko, Xue, Yongkang, Yamada, Tomohito, 2004 Regions of strong coupling between soil moisture and precipitation. Science 305, 1138-1140. doi:10.1126/science.1100217.

Pellarin, T., Ali, A., Chopin, F., Jobard, I., Bergès, J.-C., 2008. Using spaceborne surface soil moisture to constrain satellite precipitation estimates over West Africa. Geophysical Research Letters 35, L02813.

Taylor, C., Lebel, T., 1998. Observational evidence of persistent convective scale rainfall patterns. Monthly Weather Review 126, 1597-1607.

Ulaby, F.T., Moore, R.K., Fung, A.K., 1986. Microwave Remote Sensing Active and Passive. Artech House, Inc., Norwood.

Wagner, W., Scipal, K., 2000. Large-scale soil moisture mapping in Western Africa using the ERS scatterometer. IEEE Transactions on Geoscience and Remote Sensing GRS-38 (4), 1777-1782.

Wagner, W., Lemoine, G., Rott, 1999. A method for estimating soil moisture from ERS scatterometer and soil data. Remote Sensing of Environment 70, 191-207.

Zine, S., Jarlan, L., Frison, P.-L., Mougin, E., Hiernaux, P., Rudant, J.-P., 2005. Land surface parameter monitoring with ERS scatterometer data over the Sahel: a comparison between agro-pastoral and pastoral areas. Remote Sensing of Environment 96, 438-452.

Zribi, M., Le Hégarat-Mascle, S., Ottlé, C., Kammoun, B., Guerin, C., 2003. Surface soil moisture estimation from the synergetic use of the (multi-incidence and multiresolution) active microwave ERS wind scatterometer and SAR data. Remote Sensing of Environment 86, 30-41.

Zribi, M., Saux-Picart, S., André, C., Descroix, L., Ottlé, O., Kallel, A., 2006. Soil moisture mapping based on ARSAR/ENVISAT radar data over a Sahelian site. International Journal of Remote Sensing 28 (16), 3547-3565.

Zribi, M., André, C., Decharme, B., 2008. A method for soil moisture estimation in Western Africa based on ERS scatterometer. IEEE Transactions on Geoscience and Remote Sensing. 46 (2), 438-448. 